\title{
Effects of Six Particulate Metals on Osteoblast-like MG-63 and HOS Cells in vitro
}

\author{
Syuhei KURODA, Shoji TAKEDA and Masaaki NAKAMURA \\ Department of Biomaterials, Osaka Dental University \\ 8-1, Kuzuhahanazono-cho, Hirakata-shi, Osaka 573-1121, Japan
}

Received July 14, 2003/Accepted September 9, 2003

The effects of six particulate metals ( $\mathrm{Al}, \mathrm{Ti}, \mathrm{Zr}, \mathrm{Nb}, \mathrm{Ta}$ and $\mathrm{Cr}$ ) on cell viability and alkaline phosphatase (ALP) activity were studied in vitro using two types of osteoblast-like cells, MG-63 and HOS cells. The cell viability in the presence of $\mathrm{Al}, \mathrm{Ti}$ and $\mathrm{Zr}$ was depressed at lower concentrations than in the presence of $\mathrm{Nb}, \mathrm{Ta}$ and $\mathrm{Cr}$. The average sizes of the $\mathrm{Al}, \mathrm{Ti}, \mathrm{Zr}, \mathrm{Nb}, \mathrm{Ta}$ and $\mathrm{Cr}$ particulates were $6.48 \mu \mathrm{m}, 16.99 \mu \mathrm{m}, 5.07 \mu \mathrm{m}, 14.18 \mu \mathrm{m}, 8.32 \mu \mathrm{m}$ and $23.27 \mu \mathrm{m}$ respectively. The interaction of HOS cells with the particulates was more sensitive than that of MG-63 cells. $\mathrm{ALP}$ activity increased at higher concentrations only with the $\mathrm{Al}$ particulates; other experimental conditions did not exert an influence on ALP activity. These findings suggest that the cell viability of osteoblast-like cells might be influenced by particulate size and metal type, but ALP activity was not influenced by these factors.

Key words: particulate metals, osteoblast-like cells, cytotoxicity

\section{INTRODUCTION}

Metallic biomaterials have been widely used as stress-bearing implants in the medical and dental fields due to their good mechanical properties. As a result, their stressbearing functions promote metal ion dissolution and wear debris. Extensive in vitro studies have shown that particulate wear debris and dissolved metal ions have adverse effects on macrophages ${ }^{1-4)}$, monocytes $^{5,6)}$, fibroblasts ${ }^{7-9)}$, and osteoblasts ${ }^{10-12)}$. These studies have demonstrated that particulate wear debris had different effects on cells from those of bulk metals. For example, the response of cells to wear debris has been recognized as one of the major factors responsible for the loosening of orthopedic implants ${ }^{13)}$. We previously reported that 12 kinds of pure particulate metals can be roughly divided into three groups: those with direct effects due to the contact between particulates and cells, those with indirect effects due to leaching of toxic soluble ions from the particulates, and those with both direct and indirect effects ${ }^{14)}$. Evans $^{8)}$ suggested that the adverse effects depended more on the particulate nature of the material than its chemical biocompatibility. In addition, Yao et al. ${ }^{15)}$ stated that particulates of $21 \mu \mathrm{m}$ in diameter showed no effect on MG-63 or HOS osteoblast-like cells.

The objective of the present study was, therefore, to evaluate the dose-effect of six kinds of particulate metals which did not have indirect effects due to dissolution in the previous study ${ }^{14}$ and passed through a $20 \mu \mathrm{m}$-sieve, on the two human osteoblast-like cells, by analyzing 3-(4,5-dimethylthiazol-2-yl)-2,5-diphenyltetrazolium 
bromide (MTT) reduction and alkaline phosphatase (ALP) activity. These particulate metals were selected because they were important and/or additional elements for dental as well as medical uses. Moreover, there was little information about the particulate metals, except for Ti.

\section{MATERIALS AND METHODS}

\section{Particulate metals}

Six commercial pure particulate metals were used as shown in Table 1. Before use, each kind of commercial particulate metal was passed through a sieve with a $20-\mu \mathrm{m}$ aperture (IIDA Seisakusho, Osaka). The particulate size distribution of each particulate metal was measured using a laser diffraction particle size analyzer (SALD-2100, Shimadzu, Kyoto).

\section{Cells and cell cultures}

The MG-63 and HOS human osteoblast-like cell lines (American Type Culture Collection, VA) were cultured in monolayers in Dulbecco's modified Eagle medium (DMEM) (ICN Biomedicals, OH), supplemented with $2 \mathrm{mM}$ glutamine (ICN Biomedicals, OH) and $10 \mathrm{v} / \mathrm{v} \%$ fetal bovine serum (FBS) (ICN Biomedicals, OH) in a humidified atmosphere at $5 \%$ carbon dioxide in air at $37^{\circ} \mathrm{C}$.

\section{Experiment}

Before use, the weighed particulate metals were sterilized by ultraviolet irradiation for $48 \mathrm{hr}$. The original exposed concentration was prepared by suspending each particulate metal at $0.8 \mathrm{mg} / \mathrm{ml}$ in DMEM containing $2 \mathrm{mM}$ glutamine, $10 \mathrm{v} / \mathrm{v} \% \mathrm{FBS}, 50$ $\mathrm{U} / \mathrm{ml}$ penicillin, and $50 \mu \mathrm{g} / \mathrm{ml}$ streptomycin. The culture media containing the particulates were ultrasonicated for $5 \mathrm{~min}$. Dispersion of particulates was achieved by continuous vibration. Four serial dilutions were then prepared by the addition of the culture medium. This resulted in five suspensions with particulate concentrations of $0.40 \mathrm{mg} / \mathrm{cm}^{2}, 0.20 \mathrm{mg} / \mathrm{cm}^{2}, 0.10 \mathrm{mg} / \mathrm{cm}^{2}, 0.05 \mathrm{mg} / \mathrm{cm}^{2}$, and $0.025 \mathrm{mg} / \mathrm{cm}^{2}$ for each type of particulate metal. The highest concentration was determined from the concentration where the particulates did not completely surround the whole surface of

Table 1 Particulate metals and sizes used in this experiment

\begin{tabular}{crrrrr}
\hline & & & \multicolumn{3}{c}{ Distribution $(\mu \mathrm{m})$} \\
\cline { 5 - 6 } \cline { 4 - 6 } & \multirow{2}{*}{$\begin{array}{c}\text { Average } \\
(\mu \mathrm{m})\end{array}$} & $(\mu \mathrm{m})$ & $10 \% \mathrm{D}$ & $50 \% \mathrm{D}$ & $90 \% \mathrm{D}$ \\
\hline $\mathrm{Al}$ & 6.48 & 0.58 & 0.86 & 8.96 & 30.44 \\
$\mathrm{Ti}$ & 16.99 & 0.14 & 11.08 & 17.21 & 25.59 \\
$\mathrm{Zr}$ & 5.07 & 0.19 & 2.76 & 5.30 & 8.57 \\
$\mathrm{Nb}$ & 14.18 & 0.20 & 7.47 & 14.70 & 25.11 \\
$\mathrm{Ta}$ & 8.32 & 0.31 & 3.14 & 9.17 & 19.31 \\
$\mathrm{Cr}$ & 23.27 & 0.13 & 15.85 & 23.32 & 34.17 \\
\hline
\end{tabular}

${ }^{*}$ The Nilaco Corp., Tokyo 
wells.

Cells were plated in 24 -well plates at 5,000 cells $/ \mathrm{cm}^{2}$ in DMEM containing $2 \mathrm{mM}$ glutamine and $10 \mathrm{v} / \mathrm{v} \%$ FBS. After a 24 -hr incubation, the medium was removed and replaced with $1 \mathrm{ml}$ of an experimental medium containing the particulate metals. After the addition of the particulate metals, the cells were cultured in a humidified atmosphere of $5 \%$ carbon dioxide in air for an additional 4,7 days and 14 days at $37^{\circ} \mathrm{C}$.

\section{Cell viability assay}

Cell viability was examined using the tetrazolium compound 3-(4,5-dimethylthiazol-2yl)-5-(3-carboxy-methoxyphenyl)-2-(4-sulfo- phenyl)-2H-tetrazolium, inner salt (MTS) (CellTiter 96 AQueous, Promega, WI). The experimental medium was removed and replaced with a medium containing $100 \mu \mathrm{l}$ of MTS reagent in $500 \mu \mathrm{l}$ of culture medium. Then the plate was incubated for $2 \mathrm{hr}$ at $37^{\circ} \mathrm{C}$ in a humidified atmosphere of $5 \%$ carbon dioxide in air. After $2 \mathrm{hr}, 150 \mu \mathrm{l}$ of the medium was transferred into each well of the 96-well assay plate. The optical density was measured at $490 \mathrm{~nm}$ with a reference wavelength of $650 \mathrm{~nm}$ in an ELISA plate reader. The untreated controls were set to represent $100 \%$ viability. Experimental viability results were expressed as a percentage of the control.

\section{Alkaline phosphatase assays}

At the end of the culture time, the culture medium was removed and the cell layers were rinsed twice with phosphate-buffered saline $(\operatorname{PBS}(-))$. Distilled water with $0.01 \%$ Triton X-100 was added to each well. The plates were put on ice and ultrasonicated for $5 \mathrm{~min}$, and then subjected to three cycles of freezing and thawing to lyse the cells.

The protein content of the cell lysates was assayed using a modified Lowry protein assay (Pierce, IL). Forty microliters of the substrate was incubated with 200 $\mu \mathrm{l}$ of the modified Lowry protein assay reagent for $10 \mathrm{~min}$ at room temperature. Twenty microliters of diluted $1 \mathrm{~N}$ Folin-Ciocalteu reagent was added and then incubated for $30 \mathrm{~min}$ at room temperature. Serial dilutions of bovine serum albumin $(5-1000 \mu \mathrm{g} / \mathrm{ml})$ were used for a standard curve. The plate was read at $750 \mathrm{~nm}$ on an ELISA plate reader.

ALP activity was measured in the cell lysates by spectrophotometry. The substrate, $100 \mu \mathrm{l}$ of p-nitrophenyl phosphate in the appropriate buffer (SIGMA, MO), was added to $100 \mu \mathrm{l}$ of the cell lysate. The mixture was allowed to react at $37^{\circ} \mathrm{C}$ for $60 \mathrm{~min}$ and then stopped by the addition of $50 \mu \mathrm{l}$ of $3 \mathrm{~N} \mathrm{NaOH}$. Optical density was determined at $405 \mathrm{~nm}$ on an ELISA plate reader and compared with the values of a series of p-nitrophenol standards. ALP activity was expressed as nmol of pnitrophenol per hour per $\mu \mathrm{g}$ of cellular protein.

\section{Statistic analysis}

Each experiment was performed five times. Results for cell viability after 4 days 
were first analyzed for statistical significance using three-way ANOVA. Significant differences were observed with respect to cells, particulate metals and concentrations. Values were expressed as means and standard deviations, and the differences observed between the groups of particulate-exposed cells and the control cells were evaluated by Student's t test and considered significant for $\mathrm{p}$ values lower than 0.05 .

\section{RESULTS}

\section{Particulate size}

The average sizes of each particulate metal are given in Table 1 and the size distributions are shown in Fig. 1. The average diameters of the $\mathrm{Al}, \mathrm{Zr}$, and $\mathrm{Ta}$ particulates were smaller than $10 \mu \mathrm{m}$. For the $\mathrm{Zr}$ particulates, $90 \%$ of the particulates had a diameter smaller than $8.56 \mu \mathrm{m}$. The $\mathrm{Al}$ and $\mathrm{Ta}$ particulates were widely distributed, as shown in Fig. 1. The $\mathrm{Ti}$ and $\mathrm{Nb}$ particulates had a somewhat similar diameter, but the distribution curve of the $\mathrm{Nb}$ particulates shows a smaller spread than that of the $\mathrm{Ti}$ particulates (Fig. 1). The $\mathrm{Cr}$ particulates had the largest diameter of all particulates used in this study, and only $10 \%$ of the $\mathrm{Cr}$ particulates had a diameter smaller than $15.85 \mu \mathrm{m}$.

\section{Cell viability}

The cell viabilities of MG-63 cells exposed to each particulate metal for 4 days and 7 days are shown in Figs. 2 and 3, respectively. For all particulates after 4 days, cell viability decreased at the particulate concentration of $0.40 \mathrm{mg} / \mathrm{cm}^{2}$. Cell viability with the $\mathrm{Al}$ particulates was significantly lower than that with the $\mathrm{Nb}, \mathrm{Ta}$, and $\mathrm{Cr}$ particulates. The cell viability increased as the particulate concentration decreased and was similar to that of the control at the concentration of $0.025 \mathrm{mg} / \mathrm{cm}^{2}$. After

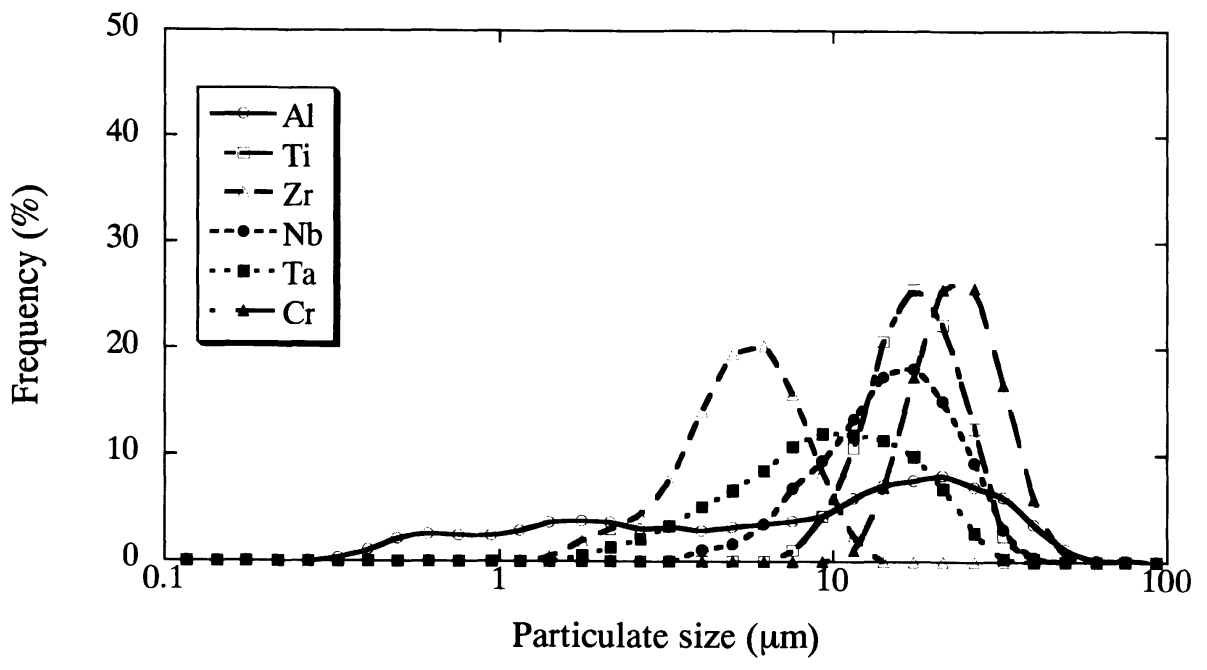

Fig. 1 Particulate distribution. 


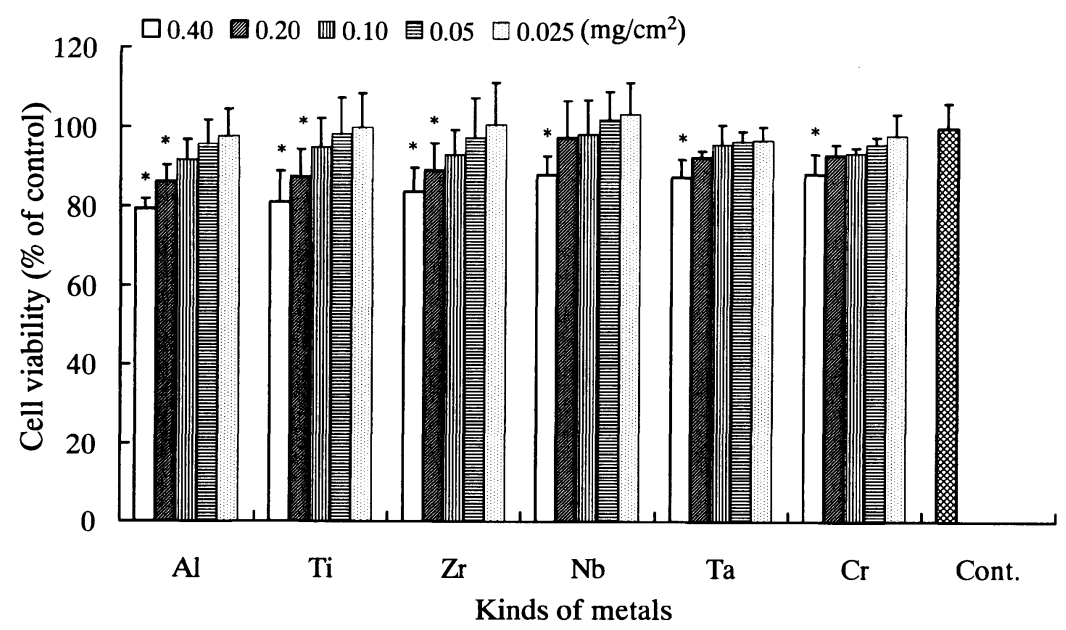

Fig. 2 Cell viability of MG-63 cells grown for 4 days in the presence of $\mathrm{Al}, \mathrm{Ti}, \mathrm{Zr}, \mathrm{Nb}, \mathrm{Ta}$ and $\mathrm{Cr}$ particulates.

*Significant differences $(p<0.05)$ from control cultures

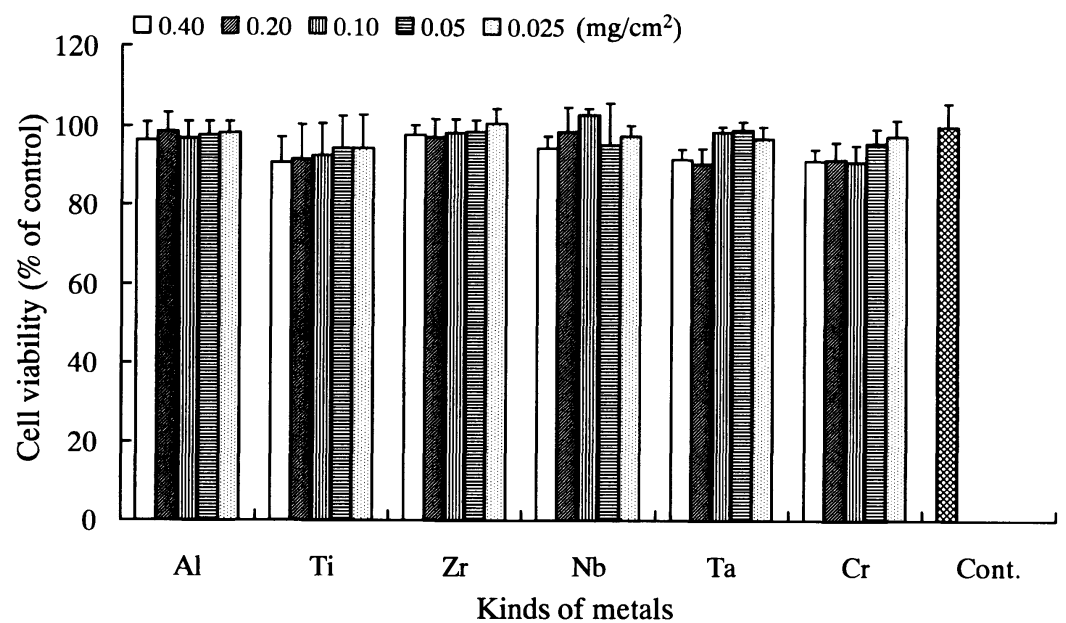

Fig. 3 Cell viability of MG-63 cells grown for 7 days in the presence of $\mathrm{Al}, \mathrm{Ti}, \mathrm{Zr}, \mathrm{Nb}, \mathrm{Ta}$ and $\mathrm{Cr}$ particulates.

7 days, the cell viability was greater than $90 \%$ for all experimental conditions (Fig. 3) with no significant differences being observed between the experimental groups and controls. In other words, cell viability increased with culture time.

The cell viability of HOS cells exposed to each particulate for 4 and 7 days are shown in Figs. 4 and 5, respectively. After 4 and 7 days of cultivation, the cell viability of HOS cells decreased at the lower concentration compared with that of 


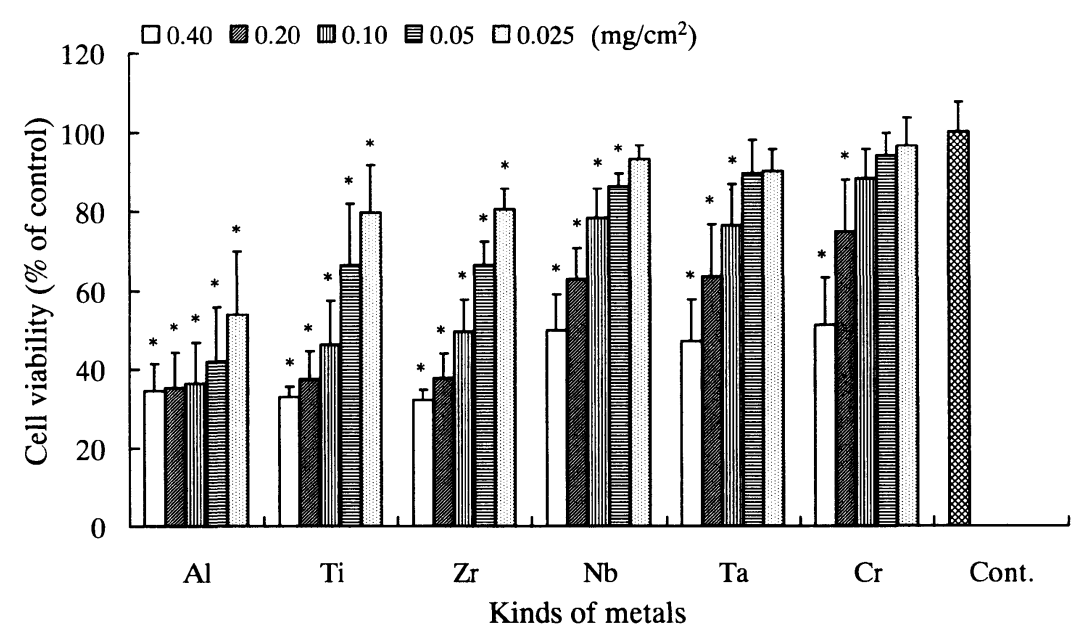

Fig. 4 Cell viability of HOS cells grown for 4 days in the presence of $\mathrm{Al}, \mathrm{Ti}, \mathrm{Zr}, \mathrm{Nb}, \mathrm{Ta}$ and $\mathrm{Cr}$ particulates.

${ }^{*}$ Significant differences $(p<0.05)$ from control cultures

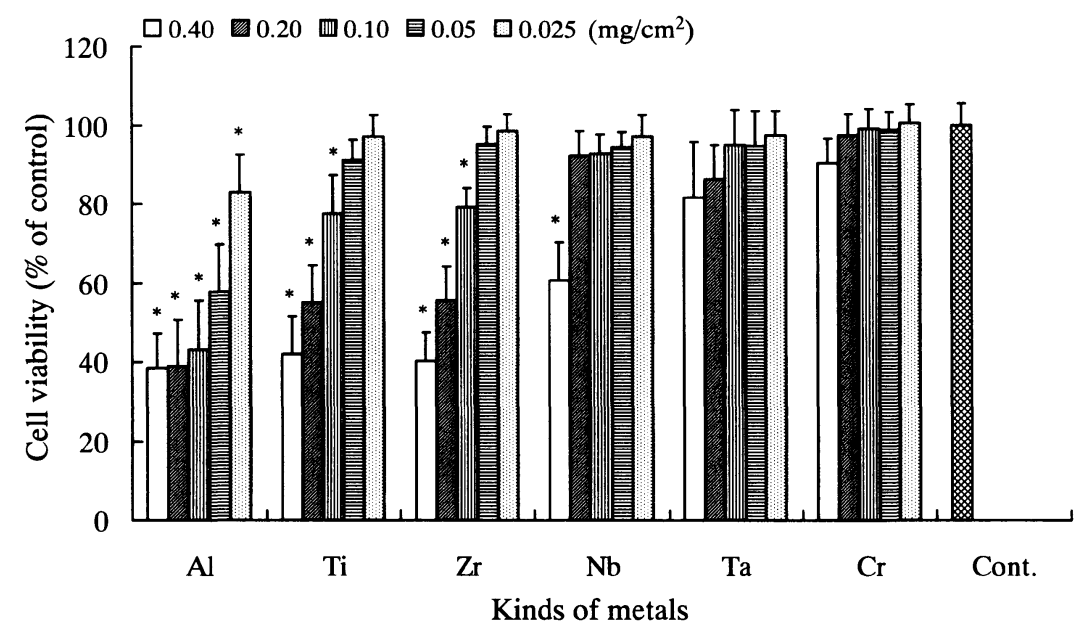

Fig. 5 Cell viability of HOS cells grown for 7 days in the presence of $\mathrm{Al}, \mathrm{Ti}, \mathrm{Zr}, \mathrm{Nb}, \mathrm{Ta}$ and $\mathrm{Cr}$ particulates.

${ }^{*}$ Significant differences $(p<0.05)$ from control cultures

MG-63 cells $(\mathrm{p}<0.05)$. At the particulate concentration of $0.40 \mathrm{mg} / \mathrm{cm}^{2}$, cell viability was $34.63 \%$ for $\mathrm{Al}$ particulates, $32.89 \%$ for $\mathrm{Ti}$ particulates, $32.13 \%$ for $\mathrm{Zr}$ particulates, $49.91 \%$ for $\mathrm{Nb}$ particulates, $46.94 \%$ for Ta particulates, and $51.23 \%$ for $\mathrm{Cr}$ particulates. As the particulate concentration decreased, cell viability increased and was greater than $80 \%$ at $0.025 \mathrm{mg} / \mathrm{cm}^{2}$ for all cells except those with the $\mathrm{Al}$ 


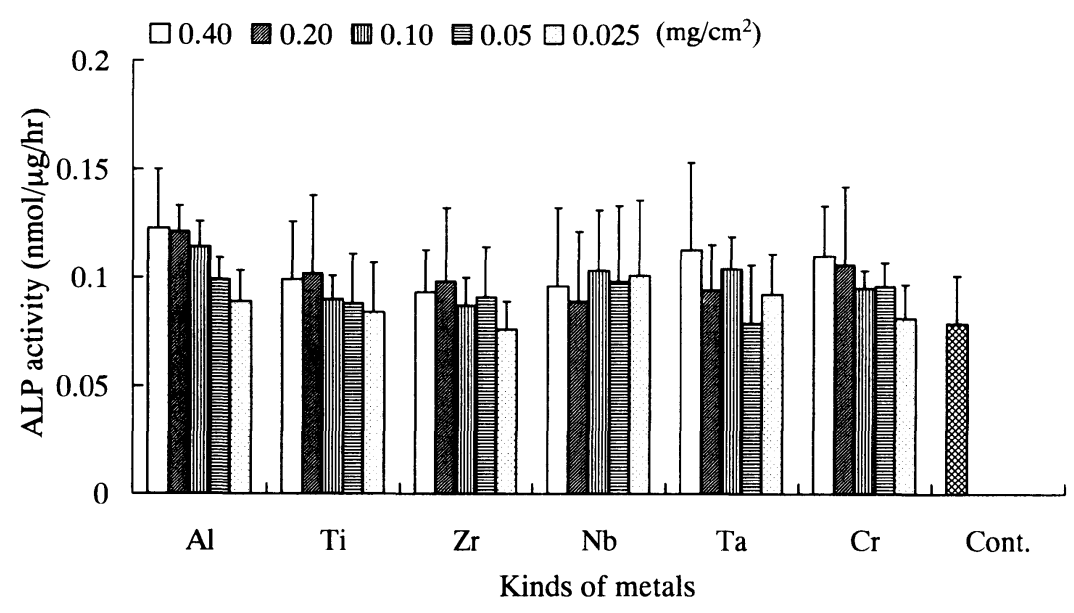

Fig. 6 Effects of particulates on ALP activity of MG-63 cells after 4 days cultivation.

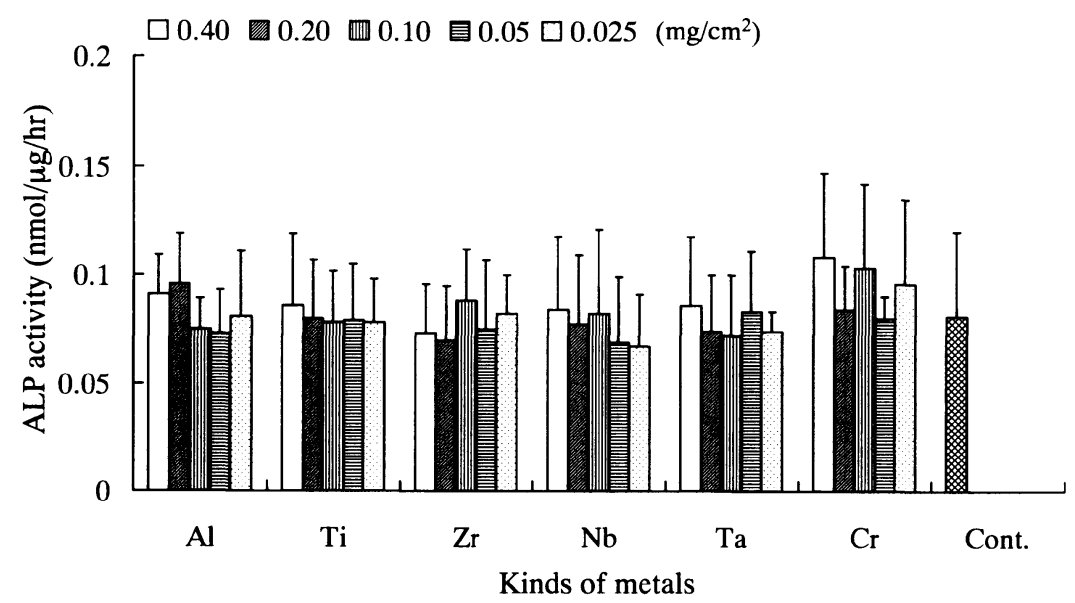

Fig. 7 Effects of particulates on ALP activity of MG-63 cells after 7 days cultivation.

particulates, which had a viability of $53.75 \%$. After 7 days, cell viability increased and was greater than $90 \%$ at $0.025 \mathrm{mg} / \mathrm{cm}^{2}$ for all cells except those with the $\mathrm{Al}$ particulates.

\section{Alkaline phosphate activity}

The results from the ALP assays of MG-63 cells are shown in Figs. 6, 7, and 8, for 4,7 and 14 days of cultivation, respectively. The ALP activity after 4 days of cultivation did not show a statistically significant difference between the controls and each experimental group in irrespective of concentrations and particulate metals. 


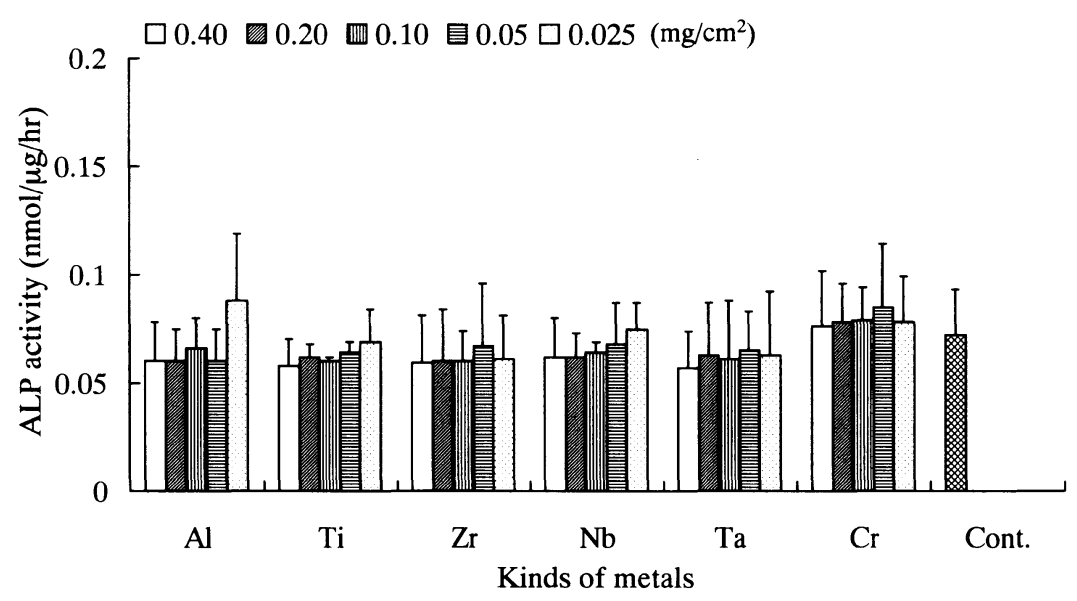

Fig. 8 Effects of particulates on ALP activity of MG-63 cells after 14 days cultivation.

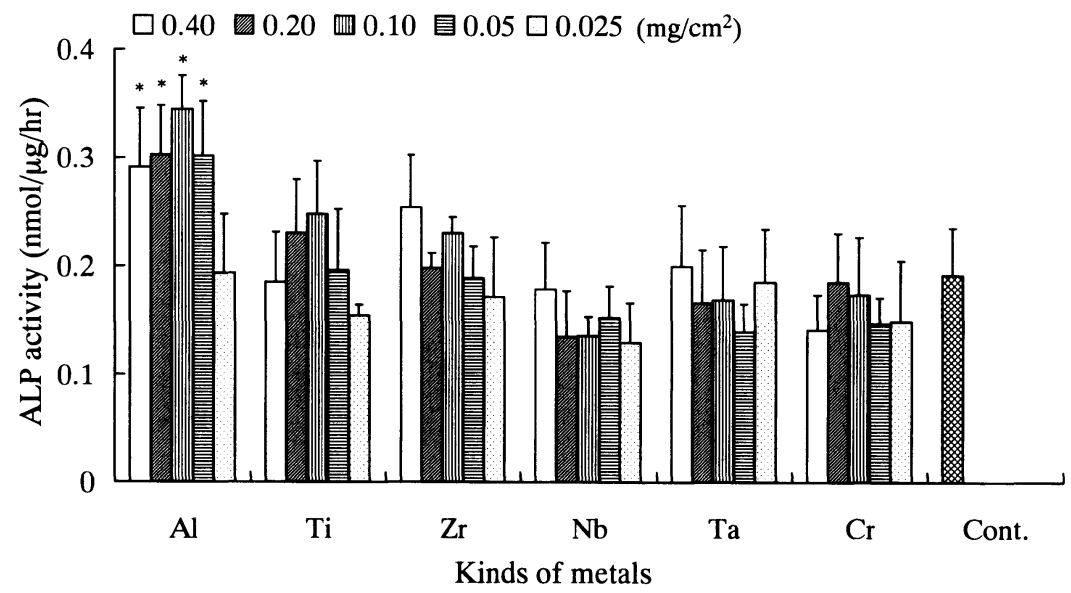

Fig. 9 Effects of particulates on ALP activity of HOS cells after 4 days cultivation.

*Significant differences $(p<0.05)$ from control cultures

ALP activity tended to decrease with culture time. The ALP activity after 7 days of cultivation also did not show a significant difference between the controls and each experimental group. The addition of particulates, except for $\mathrm{Cr}$, tended to decrease ALP activity after 14 days of cultivation, but the effect was not significant.

The results from the ALP assays of HOS cells are shown in Figs. 9, 10, and 11, for 4, 7 and 14 days of cultivation, respectively. For all three cultivation periods, the level of ALP activity in HOS cells was higher than that in MG-63 cells. The ALP activity of the $\mathrm{Al}$ particulates at $0.40,0.20,0.10$, and $0.05 \mathrm{mg} / \mathrm{cm}^{2}$ was significantly 


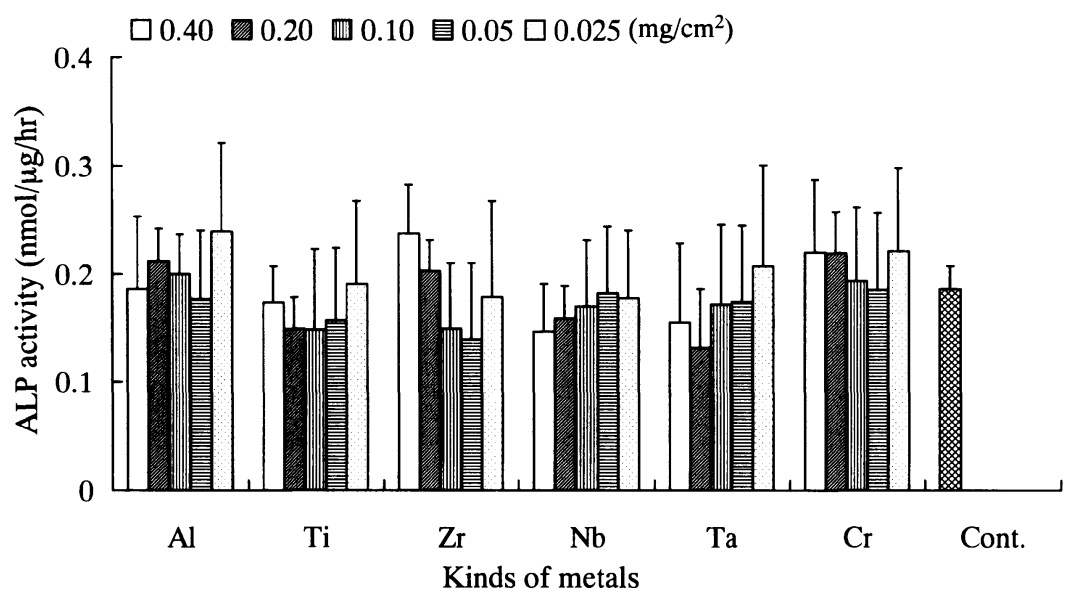

Fig. 10 Effects of particulates on ALP activity of HOS cells after 7 days cultivation.

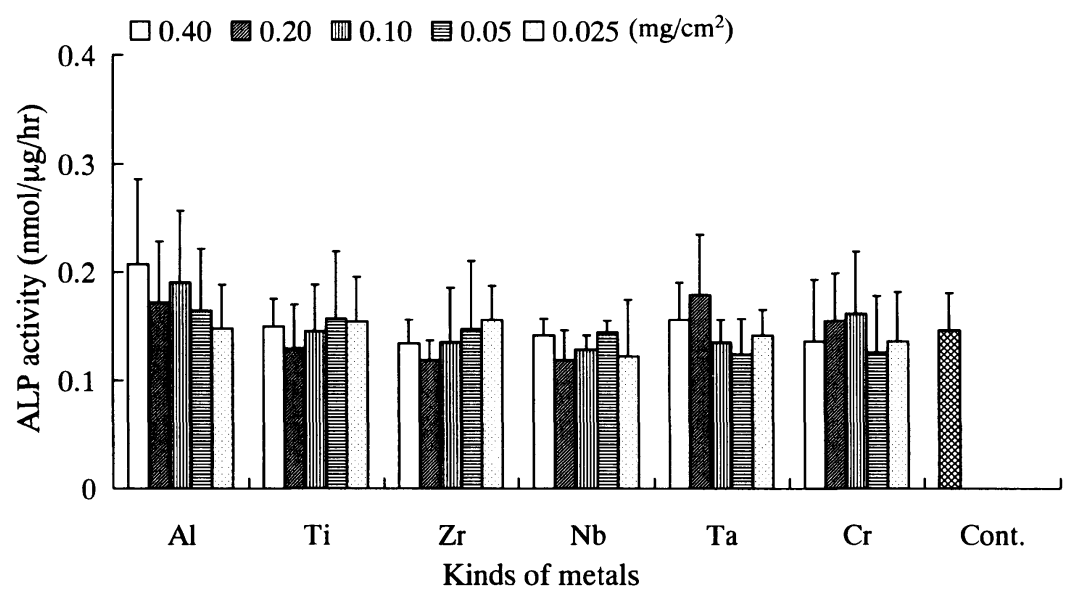

Fig. 11 Effects of particulates on ALP activity of HOS cells after 14 days cultivation.

higher after 4 days of cultivation than that of the controls. However, the other experimental conditions were not significantly different from the controls. After 7 and 14 days of cultivation, none of the experimental conditions were significantly different compared with the controls. That is to say, ALP activity had nothing to do with concentrations and particulate metals.

\section{DISCUSSION}

In the present study, we investigated the reaction of osteoblast-like cells to six kinds 
of particulate metals. Cell viability decreased at the highest concentration of each metal. However, the $\mathrm{Al}, \mathrm{Zr}$, and $\mathrm{Ti}$ particulates were cytotoxic compared with the $\mathrm{Nb}, \mathrm{Ta}$, and $\mathrm{Cr}$ particulates. The interaction of HOS osteoblast-like cells with the particulates was more sensitive than that of MG-63 osteoblast-like cells. On the other hand, ALP activity was not influenced by the particulates, except for the $\mathrm{Al}$ particulates at higher concentrations.

All particulates depressed the cell viability of both cell lines. Cell viability with the $\mathrm{Al}, \mathrm{Ti}$, and $\mathrm{Zr}$ particulates decreased compared to cell viability with the $\mathrm{Nb}, \mathrm{Ta}$, and $\mathrm{Cr}$ particulates. It is conceivable that cell viability is influenced by particulate size, concentration, composition, and dissolved ions. Okazaki et al. ${ }^{16)}$ reported that $\mathrm{Ti}, \mathrm{Zr}, \mathrm{Nb}$, and Ta particulates released only a small amount of ions and hence their extracts did not exhibit any effect on the relative growth ratio of cells. The effect on cells due to the solubility of those particulate metals was said to be negligible. On the other hand, $\mathrm{Al}$ and $\mathrm{Cr}$ particulates were reported to dissolve and decrease cell viability ${ }^{16,17)}$. However, those studies were conducted at higher concentrations than the present study and/or under dynamic extraction conditions. Therefore, the effects of the particulates in the present study may be considered to be mainly due to the direct contact of particulates with the cell membrane and the phagocytosis of osteoblast-like cells.

Particulates less than $15 \mu \mathrm{m}$ in diameter are known to be phagocytosable ${ }^{10,11,15,18-21)}$. Pioletti et al. ${ }^{11)}$ demonstrated that the phagocytosis of titanium particulates by osteoblasts is an important factor affecting their viability. Particulates less than 5$10 \mu \mathrm{m}$ in diameter might be a more important cause of cell damage than composition, as seen by their direct effect on osteoblast viability ${ }^{8)}$. Evans et al. ${ }^{22)}$ reported that toxicity due to the direct contact of hydroxyapatite particulates with cells only occurred with particulates smaller than about $5 \mu \mathrm{m}$ in diameter. Of particulate sizes in the present study, $90 \%$ of the $\mathrm{Zr}$ particulates and $50 \%$ of the $\mathrm{Al}$ and $\mathrm{Ta}$ particulates were smaller than $10 \mu \mathrm{m}$. For the $\mathrm{Nb}$ particulates, $10 \%$ were smaller than $10 \mu \mathrm{m}$. On the other hand, less than $10 \%$ of the $\mathrm{Ti}$ and $\mathrm{Cr}$ particulates were smaller than $10 \mu \mathrm{m}$. However, the cell viability with the $\mathrm{Al}, \mathrm{Ti}$, and $\mathrm{Zr}$ particulates was lower than that with the $\mathrm{Nb}, \mathrm{Ta}$, and $\mathrm{Cr}$ particulates. Our study suggested that the cell viabilities with the $\mathrm{Al}$ and $\mathrm{Zr}$ particulates were depressed by the number of particulates smaller than $10 \mu \mathrm{m}$. In particular, the cell viability with the $\mathrm{Al}$ particulates was most strongly depressed. This result suggests that the $\mathrm{Al}$ particulates may be dissolved and contain particulates smaller than $1.0 \mu \mathrm{m}$. On the other hand, the $\mathrm{Cr}$ particulates hardly influenced cell viability because they are larger particulates. However, cell viability was not always in agreement with the results of particulate size. For example, the $\mathrm{Ti}$ particulates contained larger-sized particulates than the $\mathrm{Nb}$ and $\mathrm{Ta}$ particulates. Cell viability with the Ti particulates was nevertheless depressed compared to that with the $\mathrm{Nb}$ and $\mathrm{Ta}$ particulates. The particulate number in each plate well might be related to cell viability. Since the particulate sizes and densities of the metals are different, the number of particulates exposed was different for each type at equal concentrations. When the volume was calculated from the average size by 
assuming the particulates to be spheres, the particulate number per $\mathrm{cm}^{2}$ was roughly $2,382 \times 10^{3}$ for $\mathrm{Al}$ particulates, $107 \times 10^{3}$ for $\mathrm{Ti}$ particulates, $2,827 \times 10^{3}$ for $\mathrm{Zr}$ particulates, $98 \times 10^{3}$ for Nb particulates, $250 \times 10^{3}$ for Ta particulates, and $26 \times 10^{3}$ for $\mathrm{Cr}$ particulates. Although the Ti particulates had nearly the same size and number as the $\mathrm{Nb}$ particulates, the cell viability with the $\mathrm{Ti}$ particulates decreased compared to that with the $\mathrm{Nb}$ particulates. The difference in the cell viabilities with the $\mathrm{Ti}$ and $\mathrm{Nb}$ particulates was not clarified by this study. Maloney et al. $^{23)}$ reported that particulates of different shapes might potentially influence cellular reactivity. In addition, cell viability might be influenced by composition.

Cell viability was higher after 7 days of cultivation than after 4 days for both types of cells and all six types of the particulate metals. After a cell is damaged due to the particulates, the remaining cells can proliferate, reduce the number of particulates per cell, and then allow the viability to recover.

Lohmann et $a .^{24)}$ reported the possibility that particulate size plays a role in differential cell response. The present results did not show significant differences in ALP activity among the particulates. However, Al particulates at higher concentrations tended to stimulate ALP activity. Treatment of osteoblasts with TGF- $\beta$ was reported to stimulate ALP activity and inhibit osteocalcin production ${ }^{25)}$. In addition, Thompson et $a .^{26)}$ reported that $\mathrm{Al}^{+3}$ at low concentrations appeared to stimulate ALP activity. A small amount of $\mathrm{Al}^{+3}$ might be dissolved from $\mathrm{Al}$ particulates and subsequently release the cytokines. We shall investigate this in our future studies, in which we will examine the effects of particulates on the release of cytokines and metal ion dissolution.

The six kinds of particulate metals demonstrated differences in cell viability according to the particulate size, number, and composition. These results suggest that morphological information, such as sizes, shapes and so on, might be important in evaluating the biocompatibility of wear debris produced in vivo. In addition, the findings in this present study may provide information for the assessment of the potential biocompatibility of selecting the elements in metallic biomaterials.

MG-63 and HOS cells are derived from human osteosarcoma cells and could be used as valuable tools for investigating specific aspects of bone cell function ${ }^{27)}$. However, each cell line has a different morphology: MG-63 cells are fibroblasts and HOS cells are a mixture of fibroblasts and epithelial-like cells ${ }^{28,29)}$. HOS cells have been frequently used to study transformations caused by metals and chemical carcinogens because of their sensitivity to chemical transformation ${ }^{30)}$. The difference in sensitivity might therefore be one reason for the difference between the two cell lines. In addition, these results show that the extrapolation of cytotoxic results from one kind of cell to human osteoblasts should be performed with caution. Allen et $a l .{ }^{10)}$ suggested that cell interaction with particulates could produce different cytotoxic results among different cell lines.

The findings of the present study demonstrate that particulate metals can affect the cell viability of osteoblasts. The effects will depend not only on particulate concentration and size but also on composition. It is unclear which factor contributes 
the most. Further studies are required to clarify this point. However, the decrease of cell viability at higher concentrations of all particulates suggests that the number of osteoblasts may decrease because of local accumulation of particulate wear debris due to long periods of use, and that new bone formation may be affected. Moreover, these results demonstrate that the selection of metallic biomaterials used in stressbearing locations would make it necessary to take into account not only dissolution but also wear. On the other hand, our results show that ALP activity was hardly influenced by the different kinds of particulate metals. These results suggest that other differentiation markers and pro-inflammatory mediators should be investigated in future work to obtain information about the direct interaction between particulate wear debris and osteoblasts. In addition, Evans et $a l^{31)}$ suggested that particulates show a reduced toxicity when ground in serum. Therefore, the interaction between cells and wear debris produced in vivo should be a matter of further investigation to clarify the effects of particulate wear debris with biological systems.

\section{ACKNOWLEDGMENTS}

This study was partially supported by a Grant-in-Aid for General Scientific Research (C) (2) (No.13672067) from the Ministry of Education, Science, Sports and Culture of Japan.

The authors wish to thank the members of the Department of Biomaterials, Osaka Dental University, for their kind advice and help. Part of this study was carried out using the Institute of Dental Research, Osaka Dental University.

\section{REFERENCES}

1) Glant, T. T. and Jacobs, J. J.: Response of three murine macrophage populations to particulate debris: Bone resorption in organ cultures, J Orthop Res 12:720-731, 1994.

2) Shanbhag, A.S., Macaulay, W., Stefanovic-Racid, M. and Rubash, H. E.: Nitric oxide release by macrophages in response to particulate wear debris, $J$ Biomed Mater Res 41 : 497-503, 1998.

3) Rae, T.: A study on the effects of particulate metals of orthopaedic interest on murine macrophages in vitro, $J$ Bone Joint Surg 57-B : 444-450, 1975.

4) Rae, T.: The biological response to titanium and titanium-aluminum- vanadium alloy particles I. Tissue culture studies, Biomaterials $7: 30-36,1986$.

5) Herman, J. E., Sowder, W. G., Anderson, D., Appel, A. M. and Hopson, C. N.: Polymethyl-methacrylate-induced release of bone resorbing factors, $J$ Bone Joint Surg 71-A : 1530-1541, 1989.

6) Lee, S. H., Brennan, F. R., Jacobs, J. J., Urgan, R. M., Ragasa, D. R. and Glant, T. T.: Human monocyte/marcophage response to cobalt-chromium corrosion products and titanium particles in patients with total joint replacements, $J$ Orthop $15: 40-49,1997$.

7) Maloney, W. J., Smith, R. L., Castro, F. and Schurman, D. J.: Fibroblast response to metallic debris in vitro, $J$ Bone Joint Surg 75-A : 835-844, 1993.

8) Evans, E. J.: Cell damage in vitro following direct contact with fine particles of titanium, titanium alloy and cobalt-chrome-molybdenum alloy, Biomaterials 15:713-717, 1994.

9) Mostardi, R. A., Meerbaum, S. O., Kovacik, M. W. and Gradisar, I. A.: In vitro response 
of human fibroblasts to commercially pure titanium, J Biomed Mater Res 47:60-64, 1999.

10) Allen, M.J., Myer, B. J., Millett, P.J. and Rushton, N.: The effects of particulate cobalt, chromium and cobalt-chromium alloy on human osteoblast-like cells in vitro, $J$ Bone Joint Surg 79-B : 475-482, 1997.

11) Pioletti, D. P., Takei, H., Kwon, S. Y., Wood, D. and Sung, K-L. P.: The cytotoxic effect of titanium particles phagocytosed by osteoblasts, J Biomed Mater Res 46:399-407, 1999.

12) Vermes, C., Chandrasekaran, R., Jacobs, J. J., Galante, J. O., Roebuck, K. A. and Glant, T. T.: The effects of particulate wear debris, cytokines, and growth factors on the functions of MG-63 osteoblasts, J Bone Joint Surg 83-A : 201-211, 2001.

13) Friedman, R. J., Black, J., Galante, J. O., Jacobs, J. J. and Skinner, H. B.: Current concepts in orthopaedics biomaterials and implant fixation, $J$ Bone Joint Surg 75-A : 10861109, 1993.

14) Sakai, T., Takeda, S. and Nakamura, M.: The effects of particulate metal on cell viability of osteoblast-like cells in vitro, Dent Mater $J$ 21:133-146, 2002.

15) Yao, J., Cs-Szabo, G., Jacobs, J.J., Kuettner, K. E. and Glant, T. T.: Suppression of osteoblast function by titanium particles, J Bone Joint Surg 79-A : 107-112, 1997.

16) Okazaki, Y., Rao, S., Ito, Y. and Tateishi, T.: Corrosion resistance, mechanical properties, corrosion fatigue strength and cytocompatibility of new Ti alloys without $\mathrm{Al}$ and $\mathrm{V}$, Biomaterials 19 : 1197-1215, 1998.

17) Takeda, S., Kakiuchi, H., Doi, H. and Nakamura, M.: Cytotoxicity of pure metals, $J$ Jpn Dent Mater $8: 648-652$, 1989. (in Japanese)

18) Brandwood, A., Noble, K. R. and Schindhelm, K.: Phagocytosis of carbon particles by macrophages in vitro, Biomaterials 13:646-649, 1992.

19) Greis, P. E., Georgescu, H. I., Fu, F. H. and Evans, C. H.: Particle-induced synthesis of collagenase by synovial fibroblasts: an immunocytochemical study, J Orthop Res 12 : 286$293,1994$.

20) Nordsletten, L., Hogasen, A. K. M., Konttinen, Y. T., Santavirta, S., Aspenberg, P. and Aasen, A. O.: Human monocyte stimulation by particles of hydroxyapatite, silicon carbide and diamond: in vitro studies of new prosthesis coatings, Biomaterials 17 : 1521-1527, 1996.

21) Lohmann, C. H., Schwartz, Z., Koster, G., Jahn, U., Buchhorn, G. H., MacDougall, M. J., Casasola, D., Liu, Y., Syvia, V. L., Dean, D. D. and Boyan, B. D.: Phagocytosis of wear debris by osteoblasts affects differentiation and local factor production in a manner dependent on particle composition, Biomaterials $21: 551-561,2000$.

22) Evans, E. J. and Clarke-Smith, E. M. H.: Studies on the mechanism of cell damage by finely ground hydroxyapatite particles in vitro, Clin Mater $7: 241-245,1991$.

23) Maloney, W. J., Castro, F., Schurman, D. J., Smith, R. L.: Effects of metallic debris on adult bovine articular chndrocyte methabolism in vitro, J Appl Biomater 5 : 109-115, 1994.

24) Lohmann, C. H., Dean, D. D., Koster, G., Casasola, D., Buchhorn, G. H., Fink, U., Schwartz, Z. and Boyan, B. D.: Ceramic and MMA particles differentially affect osteoblast phenotype, Biomaterials 23 : 1855-1863, 2002.

25) Bonewald, L. F., Kester, M. B., Schwartz, Z., Swain, L. D., Khare, A. G., Johnson, T. L., Leach, R.J. and Boyan, B. D.: Effects of combining transforming growth factor $\beta$ and 1,25-dihydroxyvitamin $\mathrm{D}_{3}$ on differentiation of a human osteosarcoma (MG-63), $J$ Biol Chem 267 : 8943-8949, 1992.

26) Thompson, G.J. and Puleo, D. A.: effects of sublethal metal ion concentrations on osteogenic cells derived from bone marrow stromal cells, J Appl Biomater 6:249-258, 1995.

27) Clover, J. and Gowen, M.: Are MG-63 and HOS TE85 human osteosarcoma cell lines representative models of the osteoblastic phenotype?, Bone $15: 585-591,1994$.

28) American Type Culture Collection: Product information sheet for CRL-1427.

29) American Type Culture Collection: Product information sheet for CRL-1543.

30) Miller, A.C., Mog, S., McKinney, L., Luo, L., Allen, J., Xu, J. and Page, N.: 
Neoplastic transformation of human osteoblast cells to the tumorigenic phenotype by heavy metal-tungsten alloy particles: induction of genotoxic effects, Carcinogenesis 22 : 115-125, 2001.

31) Evans, E.J. and Benjamin, M.: The effect of grinding conditions on the toxicity of cobalt-chrome-molybdenum particles in vitro, Biomaterials 8:377-384, 1987. 